\title{
Patient commentary: Incarceration is dehumanising, but good healthcare can restore dignity
}

\section{Fabien}

I arrived in prison a cocaine addict with a $£ 2000$ ( $€ 2390 ; \$ 2580)$

a week habit. My daily consumption was so extreme that I supplemented it with copious amounts of Xanax to "take the edge off." The reception prison doctor's eyes bulged in disbelief, telling me that I could die from a seizure if I wasn't properly detoxed.

Like many others, I was oblivious to the physical danger I'd been in, having neglected my health for years in addiction. I was grateful for the little cupful of benzodiazepine liquid handed though the "meds hatch" each day. It barely took the edge off the nightmare I was living, but at least I didn't die.

That was the start of a long journey for me, during which I freed myself from the addiction that had landed me a four year prison sentence. One positive aspect of being in custody is access to the healthcare that your lifestyle may have denied you in the community. During my first rehab course in prison, one participant told me that coming to prison was like having an MOT. It was a chance for you to take care of yourself, fix a few things, and get healthy.

\section{Overstretched and under-resourced}

But prison regimes often clash with effective delivery of healthcare. For example, you return from work or education at lunchtime, with only a short window to collect your lunch from the servery and your prescribed meds from a nurse before being locked in your cell. But the queue for both is so long that you're forced to make a choice. You express your frustration and complain to a member of the overstretched, under-resourced healthcare team. A verbal conflict ensues; everyone is left frustrated and defensive.

Accountability is also a challenge. Healthcare application forms regularly go missing after being handed in. When you inquire a week later, no one knows why. You're told to reapply. Another week goes by—nothing. You're told to reapply. Same again. When your appointment slip finally arrives it's passed under your cell door, and you look at the date. "But that appointment was for yesterday, guv." You're told to reapply.

The resentment builds up. Getting your repeat prescription on time can be challenging too. A woman told me that her cancer medicine had been held up on more than one occasion, sometimes for as long as a week.

It's not all bad, however. You can get good healthcare in prison, and, when it does go to plan, it makes a significant difference to your physical and mental health.

\section{Not just a number}

In the five years since my release I've worked with hundreds of prisoners and people on probation, each struggling with life challenges. Incarceration is a dehumanising experience. Every prisoner I've spoken to wants to still feel like a person, not just a number, and not be labelled as an "offender" or a "con."

Good healthcare, including a sensitive bedside manner, does much to restore a person's dignity. To be called by your name, treated with respect, and given the equivalent of community healthcare—which is your right—goes a long way to countering the daily despair of prison life.

Fabien works with service users in different prisons and probation projects and is currently with EP: IC, a consultancy collective in social and criminal justice Competing interests: I have read and understood BMJ policy on declaration of interests and have no relevant interests to declare.

Provenance and peer review: Commissioned; not externally peer reviewed. Published by the BMJ Publishing Group Limited. For permission to use (where not already granted under a licence) please go to http://group.bmj.com/group/rights-licensing/ permissions 